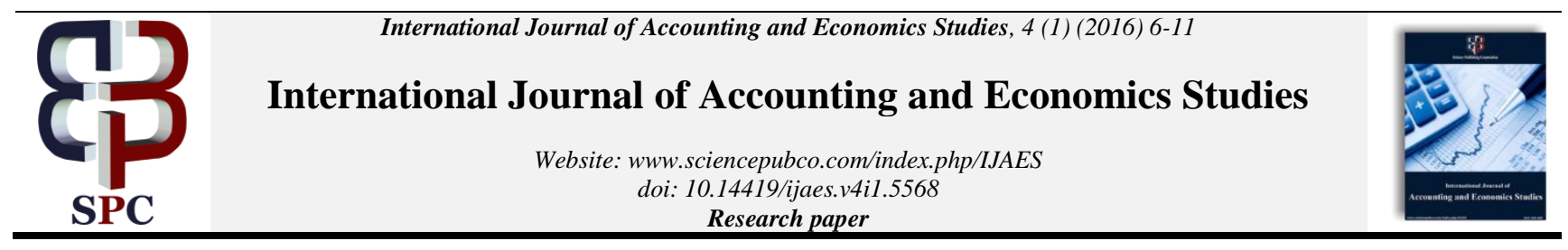

\title{
Causes of tax evasion in Tunisia: a survey study
}

\author{
Souhir NEIFAR* \\ University of Sfax, Faculty of Economics and Management, Laboratory Governance, Finance, Accounting (LFC), Tunisia \\ *Corresponding author E-mail: Neifar.souhir@yahoo.fr
}

\begin{abstract}
The purpose of this paper is to examine the causes of tax evasion in Tunisia. The paper uses the survey methodology. We use a sample of 101 participants divided into three major groups: business students' participants, medicine students' participants and other students' participants. The results show that medicine students' participants are more opposed to tax evasion than the other participants (business and others). We find also that women are more opposed to such a behavior.

While our research unprecedentedly deals with the motivations tax evasion in Tunisia, other researchers have examined this issue analyzing other contexts. The addition of other statements to this survey will enrich the list of causes of tax evasion; other economical and sociological variables will be taken into account. Our findings can be valuable to both researchers and Tunisian regulators. For researchers, this research helps to understand the motivations of tax evasion in the Tunisian context. As far as regulators are concerned, this research highlights the reduction of the tax rates as possible cure.
\end{abstract}

Keywords: Tax Evasion; Ethics; Gender; Discipline.

\section{Introduction}

Economic development is vital for every country. The lack of public finances may affect public services and therefore affect the citizens' confidence in the Governors. This problem is widespread in developing countries which have failed in providing sufficient public services and consequently failed in responding to the needs of their citizens. This situation occurs mainly because these countries have been unable to raise the tax revenues at the necessary level that allows them to grant the satisfactory public services. In addition, in such a shadow economy, people do not reveal their real taxable income and use tax planning activities in order to avoid or minimize the amount of taxes supposed to be paid (Mughal and Akram, 2012).

Generally, people may view tax evasion in three ways (McGee and Maranjyan, 2006). The first view consists in the unethical aspect of tax evasion. This view is supported by the fact that individuals have a duty to pay taxes (Smith and K., 1998). In fact, every citizen must be aware of the financial situation of his ther country and try to promote his her society. It is, therefore essential that citizens pay their tax duties in order to finance government. The second view is related to the idea that there is never any duty to pay taxes as long as the state is illegitimate (Block, 1989). The third view is entrained with the idea that tax evasion may be ethical under some circumstances and unethical under some others (as (McGee, 1998b) (McGee, 1999b)).

Flesch (1986) has described the tax avoidance as the art of managing the tax without actually breaking the law. According to Garbarino (2011), tax avoidance is defined as "a behavior aimed at reducing tax liability, which does not violate the letter of the law, but clearly violates its spirit" ((Garbarino, 2011), p283). For Otusanya (2011), tax avoidance involves the use of modes of noncriminal conduct by taxpayers to minimize or avoid tax liabilities. According to Hessing et al. (1998), tax evasion is to intentionally pay fewer taxes than the law requires; it is, therefore, a deliberate act of non-compliance. For Garbarino (2011), tax evasion is "an intentional behavior involving a direct violation of tax law in order to escape payment of taxes" ((Garbarino, 2011), p283). It is worth noting that the distinction between tax avoidance and tax evasion differs according to the jurisdiction of each country. What is legal in a country is not necessarily so in others.

Multiples are the consequences of tax evasion on the economy. This behavior can increase the heavy losses of tax distortion (Feldstein, 1999). Moreover, tax evasion can hinder the government's ability to collect tax revenues and pay its debt obligations as the case of Greece now (Lipatov, 2012). Besides, the predictions of better infrastructure, service quality and general public utility can fall by the wayside (Otusanya, 2011). Furthermore, this behavior can threaten the principle of equity (Andreoni et al., 1998).

Tunisia, like other countries, suffers from tax evasion behavior. In addition, in this country, taxes provide a major source of public funds. Trying to improve tax laws in order to limit tax evasion has been the concern of tax policy makers. Therefore, researchers as well as regulators shall be aware of the causes of tax evasion in order to propose cures for such a behavior.

Studying tax compliance, tax avoidance and tax evasion has taken the interest of economists since the 70s. Major efforts have been made to understand the decision process of taxpayers who either comply with tax laws or engage in aggressive tax activities. The several previous economics studies that have focused on tax evasion have been written from the perspective of public finance (McGee and Maranjyan, 2006). Besides, the accounting studies have analyzed mainly the determinants of tax evasion related to financial variables as well as corporate governance structure variables (Hanlon and Slemrod (2009); Chen et al. (2010); (Desai and Dharmapala, 2006) ; (Wilson, 2009) ; (Lim, 2011), etc...).

Torgler (2002) has reviewed the possible factors that may affect the tax compliance decision. Besides the economic factors, 
Torgler (2002) has underlined the importance of the social and institutional factors in determining factors that influence tax compliance decision. Therefore, analyzing the ethical and social factors of tax evasion is of great importance.

The aim of this study is to analyze the causes of tax evasion in the Tunisian context and to propose possible cures. Therefore, this study contributes to the prevailing ones by examining the reasons that make some citizens overcome their moral scruples and do not pay their real tax duties. It also analyzes the effect of gender and discipline of study on such behavior. Increasingly aware of the importance of understanding the causes of tax evasion and proposing solutions for this problem, we conduct this study which is of great helps to researchers as well as regulator in the Tunisian context.

This paper is organized as follows: section 2 presents the literature review, section 3 describes the research methodology, section 4 is dedicated to the presentation and the discussion of results, and section 5 serves as a conclusion.

\section{Literature review}

A good theory of compliance decisions is critical of designing a tax structure that discourages evasion and aggressive tax management. The economic analysis of the taxpayer's decision to engage in tax evasion goes back to the work pioneered by Allingham and Sandmo (1972). Allingham and Sandmo (1972) have made a model of taxpayer's decision to evade taxes facing to the risk of being caught. The risk arises from the possibility that an audit is conducted by tax authorities. According to Allingham and Sandmo (1972), a rational taxpayer must allocate the income between a safe asset (reported income) and a risky asset (tax evasion). Allingham and Sandmo (1972) have analytically shown that when taxpayers are averse to risk, evasion decreases as the probability of detection and penalty increases. Allingham's and Sandmo's (1972) research has built the initial framework that focuses on how the probability of detection, penalty, tax rates, and tax liability, influences the decision of the taxpayer about tax evasion. Yitzhaki (1974) has changed the model using a different specification of penalty that is considered more consistent with reality, which has since become the standard formulation of tax evasion.

Analyzing the Nigerian context, Uadiale et al. (2010) have examined the impact of cultural factors (e.g. trust in government) and legal enforcement on individual's tax evasion behavior. The results of this study show the positive effect of trust in government and legal enforcement on tax evasion behavior, but no significant effect of religious variables on this behavior is revealed.

Comparing behaviors of people regarding tax evasion in Netherlands, France and Belgium, Lefebvre et al. (2011) have found that people in the Netherlands and France use more tax evasion. Using the experimental techniques, Boylan and Sprinkle (2001) have analyzed the effect of tax rate increase on the reported taxable income. They have found that in the case of endowed income, participants react to the tax rate increase by reporting less taxable income. However, in the case of earned income, participants react to the tax rate increase by reporting more taxable income. Pommerehne et al. (1994) have analyzed the interaction between tax morale and the performance of different political systems. They have found that grievances increase the level of tax evasion. Using an experiment involving 12 sessions of 15 participants, Fortin et al. (2007) have analyzed the impact of social interactions on tax evasion behavior. The results indicate that "perceived unfair taxation" encourages tax evasion behavior.

Bobek et al. (2012) have explored the role of social norms in tax compliance decision. Using an experiment on 174 participants, they have shown that personal norms (individuals' standards for behavior/ethical beliefs) as well as the subjective norms (as the expectations of others) directly affect tax compliance decisions, however "injunctive norms" and other "descriptive norms" affect it indirectly.
Buehn and Schneider (2012) have developed a time series of tax evasion for 38 OECD countries over the period 1999 to 2010 based on the proportion of the shadow economy. This study has shown that the country with the highest average value of tax evasion is Mexico followed by Turkey. Buehn and Schneider (2012) have reported that the united States has the lowest rate of tax evasion.

Mughal and Akram (2012) Have examined the reasons of tax avoidance and evasion in the Pakistani context. They have found that the absence of public enlightenment campaigns; the lack of adequate tax incentives; the poor relationship between o tax payers \& authority; the proliferation of taxes and the illiteracy of tax calculation are the major causes of tax evasion behavior in Pakistan.

McGee and Maranjyan (2006) Have analyzed the causes and implications of tax evasion in the Armenian Context. This study has used a survey of Armenian theology and business students as methodology. The results of this study have shown the widespread of moral support for tax evasion.

Few articles have examined tax evasion from the religious perspective. The study of Gronbacher (1998) has concentrated on the tax evasion issue from the perspectives of Catholic social and classical liberalism. McGee (1998a) and McGee (1999a) have interpreted the various Christian views from a material perspective Using experiment technique, Balafoutasa et al. (2015) have investigated the effects of taxpayers revealed intentions on the performance of the market. The findings suggest that if the seller has an informational advantage over the consumers, those latter's are advised to be wary of proposing to evade taxes.

In their study analyzing the tax evasion behavior in trade transactions, Levin and Widell (2014) have found that tax evasion seems to be more severe in trade between Kenya and Tanzania than the one between the United Kingdom and Kenya/Tanzania. Levin and Widell (2014) have also shown that the tax evasion coefficient in the Kenya-United Kingdom trades is lower than the TanzanianUnited Kingdom ones.

McGee and Yoon (2014) have examined the ethics of tax evasion and the opinions of citizens about this behavior in the South Korean context. They have found that South Koreans are strongly opposed to tax evasion in general. Besides, they have reported that men and women are equally opposed to tax evasion. McGee and Yoon (2014) have also highlighted that older people are more opposed to tax evasion than younger people in South Korea. Moreover, the results of this study have shown that religion and confidence in government are not significant variables.

Gender has been also analyzed. Based on a survey analyzing the International Business Academics, McGee (2005) has found that women are significantly more opposed to tax evasion than men. However, examining the attitudes of business students in the Romanian context, McGee and Maranjyan (2006) have found the opposite.

Moreover, the attitude of respondents towards the ethical aspect of tax evasion differs from one country to another. In addition, studying the attitudes of business students in the Romanian context, McGee and Maranjyan (2006) have shown that, generally, respondents believe that tax evasion is ethically justified. However, by analyzing the German context, McGee et al. (2005) have found that respondents are strongly opposed to tax evasion.

\section{Research methodology}

A survey instrument was used in order to collect data. The respondents were students in the city of Sfax Tunisia. The survey was distributed to groups of business, medicine and other students in the University of Sfax.

A seven-point Likert scale was used. In each item, participants were asked to insert a number in order to indicate the level of their agreement or disagreement. The statements were derived from the study of McGee and Maranjyan (2006) that is partly from the thesis of Crowe (1944). 
In our study, we divide our whole sample into three groups: business students, medicine students and other students.

The details of our sample are described in table 1 .

Table 1 : Participant Profile

\begin{tabular}{ll} 
& \\
\hline Business students & 33 \\
\hline Medicine students & 35 \\
Other students & 33 \\
$=$ Total of the sample & 101 \\
\hline
\end{tabular}

In our study, we test the following hypotheses:

$\mathrm{H} 1$ : All groups will fall into the category that believes tax evasion is sometimes ethical.

$\mathrm{H} 2$ : There are differences in the three groups concerning the ethical aspect of tax evasion.

H3: Women are more opposed to tax evasion than men.

The different statements of our survey are described in table 2 .

\begin{tabular}{ll}
\multicolumn{1}{c}{ Table 2 : Survey Statements } \\
\hline $\mathrm{N}$ & Statements \\
\hline 1. & $\begin{array}{l}\text { Tax evasion is ethical if tax rates are too high. } \\
\text { Tax evasion is ethical even if tax rates are not too high. } \\
\text { 3. }\end{array}$ \\
Tax evasion is ethical if the tax system is unfair. \\
T. $\begin{array}{l}\text { Tax evasion is ethical if a large portion of the money collected is } \\
\text { wasted. }\end{array}$ \\
Tax evasion is ethical even if most of the money collected is spent \\
wisely.
\end{tabular}

\section{Results analysis}

\subsection{Descriptive statistics}

In order to ensure better understanding of our sample, we proceed to the descriptive statistics.

Table 3 and 4 summarize the descriptive statistics of our sample.

Table 3: Sample by Discipline of Study

\begin{tabular}{lll}
\hline \multirow{2}{*}{ Discipline } & Total sample & \\
& Number & Overall \\
\hline Business participants & 33 & $32,67 \%$ \\
Doctor participants & 35 & $34,65 \%$ \\
Other participants & 33 & $32,67 \%$ \\
\hline
\end{tabular}

Table 4: Sample by Gender of Respondents

\begin{tabular}{lllll}
\hline \multicolumn{5}{c}{ Table 4: } \\
& Men & \multicolumn{3}{c}{ Women } \\
& Number & Overall & Number & Overall \\
\hline Total sample & 42 & $41,58 \%$ & 59 & $58,42 \%$ \\
Business students & 13 & $39,39 \%$ & 20 & $60.61 \%$ \\
Medicine students & 13 & 37.14 & 22 & 62.86 \\
Other students & 16 & 48.48 & 17 & 51.52 \\
\hline
\end{tabular}

As shown in tables 3 and 4, business participants represent $32.67 \%$ of our sample. $60.61 \%$ of business respondents are women. Doctor participants represent $34.65 \%$ of the total sample; $62.86 \%$ are women. Other participants represent $32.67 \%$ and $48.48 \%$ of this category are men. Note that the category of other students includes mainly students from engineering and computer science disciplines.
In general, our sample is composed of $41.58 \%$ men and $58.42 \%$ women.

\subsection{Hypotheses analysis}

In order to test our first hypothesis (H1: All groups believe that tax evasion is sometimes ethical), we have calculated the average score of each item for each group of our study (table 5).

Table 5: Average Score (H1)

\begin{tabular}{lllll}
\hline Statements & Overall & $\begin{array}{l}\text { Medicine } \\
\text { students }\end{array}$ & $\begin{array}{l}\text { Business } \\
\text { students }\end{array}$ & $\begin{array}{l}\text { Other } \\
\text { students }\end{array}$ \\
\hline 1 & 4,990099 & 5,457142 & 5,181818 & 4,30303 \\
2 & 6,306930 & 6,085714 & 6,363636 & 6,484848 \\
3 & 4,524752 & 5,228571 & 4,636363 & 3,666666 \\
4 & 4,930693 & 5,257142 & 5,030303 & 4,484848 \\
5 & 6,227722 & 6,428571 & 5,909090 & 6,333333 \\
6 & 5,118811 & 5,542857 & 4,818181 & 4,969696 \\
7 & 6,148514 & 5,942857 & 5,969696 & 6,545454 \\
8 & 6 & 6,342857 & 5,969696 & 5,666666 \\
9 & 6,079207 & 6,171428 & 5,878787 & 6,181818 \\
10 & 5,752475 & 5,714285 & 5,909090 & 5,636363 \\
11 & 4,445544 & 5,028571 & 4,696969 & 3,575757 \\
12 & 5,693069 & 5,714285 & 5,848484 & 5,515151 \\
13 & 5,306930 & 5,742857 & 5,121212 & 5,030303 \\
14 & 5,940594 & 6,457142 & 5,424242 & 5,909090 \\
Average of total & 5,533239 & 5,793877 & 5,482683 & 5,307359 \\
14 statements & & & & \\
\hline & & & &
\end{tabular}

As suggested by McGee and Maranjyan (2006), tax evasion is considered as sometimes ethical if scores are between 2 and 6 ; it is considered to be never ethical for scores that are 6.00 or higher and it is ethical for scores less than 2 ; it is considered always ethical if the score is less than 2. Our results show that on average, our survey statements equal to 5,533 (between 2 and 6), which confirm the idea that tax evasion is sometimes ethical. In our study, we don't have any statements that have the score less than 2, which means that none of our statements entail the idea that tax evasion is always ethical. We have four statements involving the non-ethical aspect of tax evasion which are:

- Tax evasion is ethical even if tax rates are not too high.

- Tax evasion is ethical even if most of the money collected is spent wisely.

- Tax evasion is ethical even if a large portion of the money collected is spent on projects that do benefit me.

- Tax evasion is ethical if a large portion of the money collected is spent on projects that do not benefit me.

In order to test our second hypothesis (H2: There are differences in the three groups concerning the ethical aspect of tax evasion), we have calculated the average score of each item for each group of our study and we have worked out the differences between these averages (tables 6, 7 and 8).

Table 6: Inter-Group Differences (Differences between Business and Medicine Students)

\begin{tabular}{lllll} 
Statements & $\begin{array}{l}\text { Average } \\
\text { Medicine } \\
\text { students }\end{array}$ & $\begin{array}{l}\text { Business } \\
\text { students }\end{array}$ & $\begin{array}{l}\text { Differences } \\
\text { Medicine } \\
\text { students }\end{array}$ & $\begin{array}{l}\text { Business } \\
\text { students }\end{array}$ \\
\hline 1 & 5,4571 & 5,1818 & 0,2753 & \\
2 & 6,0857 & 6,3636 & & 0,2779 \\
3 & 5,2286 & 4,6364 & 0,5922 & \\
4 & 5,2571 & 5,0303 & 0,2268 & \\
5 & 6,4286 & 5,9091 & 0,5195 & \\
6 & 5,5429 & 4,8182 & 0,7247 & \\
7 & 5,9429 & 5,9697 & & 0,0268 \\
8 & 6,3429 & 5,9697 & 0,3732 & \\
9 & 6,1714 & 5,8788 & 0,2926 & 0,1948 \\
10 & 5,7143 & 5,9091 & & \\
11 & 5,0286 & 4,6970 & 0,3316 & 0,1342 \\
12 & 5,7143 & 5,8485 & & \\
13 & 5,7429 & 5,1212 & 0,6216 & \\
14 & 6,4571 & 5,4242 & 1,0329 & \\
Average score & & & & \\
for all & 5,7939 & 5,4827 & 0,3565 & \\
14 statements & & & & \\
\hline
\end{tabular}


Table 7: Inter-Group Differences (Differences between Medicine Students and other Students)

\begin{tabular}{lllll}
\hline Statements & $\begin{array}{l}\text { Average } \\
\text { Medicine } \\
\text { students }\end{array}$ & $\begin{array}{l}\text { Other stu- } \\
\text { dents }\end{array}$ & $\begin{array}{l}\text { Differences } \\
\text { Medicine } \\
\text { students }\end{array}$ & $\begin{array}{l}\text { Other } \\
\text { students }\end{array}$ \\
\hline 1 & 5,4571 & 4,3030 & 1,1541 & 0,3991 \\
2 & 6,0857 & 6,4848 & & \\
3 & 5,2286 & 3,6667 & 1,5619 & \\
4 & 5,2571 & 4,4848 & 0,7723 & \\
5 & 6,4286 & 6,3333 & 0,0952 & \\
6 & 5,5429 & 4,9697 & 0,5732 & 0,6026 \\
7 & 5,9429 & 6,5455 & & \\
8 & 6,3429 & 5,6667 & 0,6762 & \\
9 & 6,1714 & 6,1818 & & \\
10 & 5,7143 & 5,6364 & 0,0779 & \\
11 & 5,0286 & 3,5758 & 1,4528 & \\
12 & 5,7143 & 5,5152 & 0,1991 & \\
13 & 5,7429 & 5,0303 & 0,7126 & \\
14 & 6,4571 & 5,9091 & 0,5481 & \\
Total of & 5,7939 & 5,3074 & 0,5588 & \\
14 statements & & & & \\
\hline
\end{tabular}

Table 8: Inter-Group Differences (Differences between Business Students and Other Students)

\begin{tabular}{lllll} 
Statements & $\begin{array}{l}\text { Average } \\
\text { Business } \\
\text { students }\end{array}$ & $\begin{array}{l}\text { Other } \\
\text { students }\end{array}$ & $\begin{array}{l}\text { Differences } \\
\text { Business } \\
\text { students }\end{array}$ & $\begin{array}{l}\text { Other } \\
\text { students }\end{array}$ \\
\hline 1 & 5,1818 & 4,3030 & 0,8788 & \\
2 & 6,3636 & 6,4848 & & 0,1212 \\
3 & 4,6364 & 3,6667 & 0,9697 & \\
4 & 5,0303 & 4,4848 & 0,5455 & \\
5 & 5,9091 & 6,3333 & & 0,4242 \\
6 & 4,8182 & 4,9697 & & 0,1515 \\
7 & 5,9697 & 6,5455 & & 0,5758 \\
8 & 5,9697 & 5,6667 & 0,3030 & $-0,3030$ \\
9 & 5,8788 & 6,1818 & & 0,3030 \\
10 & 5,9091 & 5,6364 & 0,2727 & $-0,2727$ \\
11 & 4,6970 & 3,5758 & 1,1212 & \\
12 & 5,8485 & 5,5152 & 0,3333 & \\
13 & 5,1212 & 5,0303 & 0,0909 & \\
14 & 5,4242 & 5,9091 & & 0,4848 \\
Average score & & & & 0,1061 \\
for all & 5,4827 & 5,3074 & 0,3225 & \\
14 statement & & & & \\
\hline
\end{tabular}

Relying on the definition of significance chosen from McGee's and Maranjyan's (2006) study [ having higher scores for 8 out of 14 statements], we report the significant differences in attitudes towards the ethical aspect of tax evasion between medicine students and business students in one hand, and between medicine students and other students in other hands. Therefore, we report that medicine students are more opposed to tax evasion than business and other participants.

In order to test our second hypothesis (H3: Women are more opposed to tax evasion than men), we have calculated the average score of each item for each group of our study and we have worked out the differences between these averages (table 9).

Table 9: Differences in Participants by Gender

\begin{tabular}{lllll}
\multicolumn{4}{c}{ Table 9: Differences in Participants by Gender } \\
\hline \multirow{2}{*}{ Statements } & \multicolumn{3}{c}{ Total sample } & \multicolumn{2}{c}{ Differences } \\
& Men & Women & Men & Women \\
\hline 1 & 5,1667 & 4,8644 & 0,3023 & \\
2 & 6,0476 & 6,4915 & & 0,4439 \\
3 & 4,381 & 4,6271 & & 0,2462 \\
4 & 5,119 & 4,7966 & 0,3224 & \\
5 & 5,9524 & 6,4237 & & 0,4713 \\
6 & 4,7857 & 5,3559 & & 0,5702 \\
7 & 6,119 & 6,1695 & & 0,0504 \\
8 & 5,9048 & 6,0678 & & 0,163 \\
9 & 5,7857 & 6,2881 & & 0,5024 \\
10 & 5,3095 & 6,0678 & & 0,7583 \\
11 & 4,381 & 4,4915 & & 0,1106 \\
12 & 5,6667 & 5,7119 & & 0,0452 \\
13 & 4,9524 & 5,5593 & & 0,6069 \\
14 & 5,7857 & 6,0508 & & 0,2651 \\
Total of 14 Statements & 5,3827 & 5,6404 & 0,0446 & 0,3024 \\
\hline
\end{tabular}

Our results (table 9) show that the significant differences that exist between men's and women's attitudes towards the ethical aspect of tax evasion (women's differences are higher with 12 statements- more than 8).

Table 10 ranks the different statements (from the statement that respondents- oppose less to those that respondents- -oppose more). This ranking helps understand the causes of tax evasion in the Tunisian context.

Table 10: Ranking of Items (Causes of Tax Evasion)

\begin{tabular}{|c|c|c|}
\hline Rank & Statements & Score \\
\hline 1 & $\begin{array}{l}\text { Tax evasion is ethical if a significant portion of the } \\
\text { money collected winds up in the pockets of corrupt } \\
\text { politicians or their families and friends. }\end{array}$ & 4,44554455 \\
\hline 2 & Tax evasion is ethical if the tax system is unfair. & 4,52475248 \\
\hline 3 & $\begin{array}{l}\text { Tax evasion is ethical if a large portion of the } \\
\text { money collected is wasted. }\end{array}$ & 4,93069307 \\
\hline 4 & Tax evasion is ethical if tax rates are too high. & 4,99009901 \\
\hline 5 & $\begin{array}{l}\text { Tax evasion is ethical if a large portion of the } \\
\text { money collected is spent on projects that I morally } \\
\text { disapprove of. }\end{array}$ & 5,11881188 \\
\hline 6 & Tax evasion is ethical if I can't afford to pay. & 5,30693069 \\
\hline 7 & $\begin{array}{l}\text { Tax evasion is ethical if the probability of getting } \\
\text { caught is low. }\end{array}$ & 5,69306931 \\
\hline 8 & Tax evasion is ethical if everyone is doing it. & 5,75247525 \\
\hline 9 & $\begin{array}{l}\text { Tax evasion is ethical even if it means that if I pay } \\
\text { less, others will have to pay more. }\end{array}$ & 5,94059406 \\
\hline 10 & $\begin{array}{l}\text { Tax evasion is ethical if a large portion of the } \\
\text { money collected is spent on projects that do not } \\
\text { benefit me. }\end{array}$ & 6 \\
\hline 11 & $\begin{array}{l}\text { Tax evasion is ethical even if a large portion of the } \\
\text { money collected is spent on projects that do benefit } \\
\text { me. }\end{array}$ & 6,07920792 \\
\hline 12 & $\begin{array}{l}\text { Tax evasion is ethical even if a large portion of the } \\
\text { money collected is spent on worthy projects. }\end{array}$ & 6,14851485 \\
\hline 13 & $\begin{array}{l}\text { Tax evasion is ethical even if most of the money } \\
\text { collected is spent wisely. }\end{array}$ & 6,22772277 \\
\hline 14 & $\begin{array}{l}\text { Tax evasion is ethical even if tax rates are not too } \\
\text { high. }\end{array}$ & 6,30693069 \\
\hline
\end{tabular}

As reported in table 10, the two major causes of tax evasion are related to trust in government (statements number 1 and 3). These causes are classified as political ones, and cures can be established over time. Our result confirms the study of Uadiale et al. (2010) that has examined the Nigerian context and suggested that trust in government may reduce tax evasion behavior.

The second cause of tax evasion is related to the nature of the tax system (unfair). Unfairness can manifest in the possibility of the use of a flat tax rate for some categories of personal tax income (under some condition). Our results are similar to those of McGee and Maranjyan (2006) analyzing the Armenian context. They have found that the unfair tax system is the most important cause of tax evasion (Ranked 1 in their study).

The fourth cause of tax evasion is related to the tax rate. Citizens assume that tax evasion is sometimes ethical, because they believe that they pay more than it should be. In order to analyze this reason, we may compare the Tunisian tax rates with the international standards of tax rates. In his study, Alm (2015) has studied this issue and has highlighted that Tunisia's tax rates (both personal income tax rate and corporate tax rate ) are generally above the international levels.

As a possible cure to this reason, we can propose the reduction of tax rates. In order to estimate the possible application of such a decision, let us provide the following simple example. An individual (person or firm) is taxed according to his/her taxable income. Therefore, the total tax revenue can be expressed as follows:

$\mathrm{R}=\mathrm{t} \times \mathrm{N} \times \mathrm{W}$

Where:

$\mathrm{R}=$ Total tax revenue

$\mathrm{t}=$ Tax rate

$\mathrm{N}=$ Number of individual

$\mathrm{W}=$ Taxable income 
The number of taxpayers and the reported taxable income are related to the tax rate. Also, tax evasion decreases when tax rates decreases. Therefore, reductions of the tax rates cannot menace the funds of a country if the number of taxpayers' increases and the taxable income increases (tax evasion decrease). A simulation of an effective tax rate can be therefore useful for such target. Another cure can also be proposed. As the majority of taxpayer are opposed e to direct taxes more than the indirect ones, therefore, reducing the first type of taxes and replacing the deficit by increasing indirect taxes can be useful. This solution is also recommended as Tunisia is considered as a relatively heavy user of direct taxes and relatively light user of indirect taxes ( as reported by Alm, (2015)).

\section{Conclusion}

The present study aims at examining the attitudes of Tunisian people towards tax evasion in order to identify the causes and to propose the cures. In our study, we have used a survey methodology and we have interviewed 101 respondents divided into three groups: business students, medicine students and other students. The results of our study show that medicine students are more opposed to tax evasion than business students and other students. Besides, we have found that women are more opposite to tax evasion than men.

The findings of our research provide a pioneering work on the causes of tax evasion in Tunisia. We have highlighted three major groups of causes of tax evasion: trust in government, tax system unfairness and the high tax rate. Besides, we have tried to propose possible cures for tax evasion. However, more empirical work and detailed empirical researches are recommended. In addition, the simulation of an optimum additional indirect tax rate modifications followed by the reduction of direct tax rates is an interesting research topic for future researches.

\section{References}

[1] Allingham, M. \& Sandmo, A. 1972. Income Tax Evasion: A Theoretical Analysis Journal Of Public Economics, 1, 323 -338. http://dx.doi.org/10.1016/0047-2727(72)90010-2.

[2] Alm, J. 2015. Analyzing And Reforming Tunisia's Tax System. Http://Econ.Tulane.Edu/: Tulane Economics Working Paper Series.

[3] Andreoni, J., Erard, B. \& Feinstein, J. 1998. Tax Compliance. Journal Of Economic Literature, 36, 818-860.

[4] Balafoutasa, L., Beckb, A., Kerschbamer, R. \& Matthias, S. 2015. The Hidden Costs Of Tax Evasion.: Collaborative Tax Evasion In Markets For Expert Services. Journal Of Public Economics, 129 14-25. http://dx.doi.org/10.1016/j.jpubeco.2015.06.003.

[5] Bibi, S. \& Duclos, J.-Y. 2007. Poverty-Decreasing Indirect Tax Reforms: Evidence From Tunisia. International Tax And Public Finance, 14, 165-190. http://dx.doi.org/10.1007/s10797-006-8879$\mathrm{x}$.

[6] Block, W. 1989. The Justification Of Taxation In The Public Finance Literature: A Critique. Journal Of Public Finance And Public Choice, 3, 141-158.

[7] Bobek, D. D., Hageman, A. M. \& Kelliher, C. F. 2012. Analyzing The Role Of Social Norms In Tax Compliance Behavior. Journal Of Business Ethics, 115, 451-468. http://dx.doi.org/10.1007/s10551-012-1390-7.

[8] Boylan, S. \& Sprinkle, G. 2001. Experimental Evidence On The Relation Between Tax Rates And Compliance: The Effect Of Earned Vs. Endowed Income. Journal Of The American Taxation Association, 23, 75-90. http://dx.doi.org/10.2308/jata.2001.23.1.75.

[9] Buehn, A. \& Schneider, F. 2012. Size And Development Of Tax Evasion In 38 Oecd Countries: What Do We (Not) Know? Cesifo Working Paper No. 4004, Category 1: Public Finance.

[10] Chen, S., Chen, X., Cheng, Q. \& Shevlin, T. 2010. Are Family firms More Tax Aggressive Than Non-Family firms? Journal Of Financial Economics 95, 41-61 http://dx.doi.org/10.1016/j.jfineco.2009.02.003.

[11] Coricelli, G., Joffily, M., Montmarquette, C. \& Villeval, M. C. 2007. Tax Evasion: Cheating Rationally Or Deciding Emotionally? Hal-00196332.
[12] Crowe, M. T. 1944. The Moral Obligation Of Paying Just Taxes. The Catholic University Of America Studies In Sacred Theology No. 84.

[13] Desai, M. \& Dharmapala, D. 2006. Corporate Tax Avoidance And High-Powered Incentives. Journal Of Financial Economics, 79. http://dx.doi.org/10.1016/j.jfineco.2005.02.002.

[14] Feldstein, M. 1999. Tax Avoidance And The Deadweight Loss Of The Income Tax. Review Of Economics And Statistics, 81, 674 680. http://dx.doi.org/10.1162/003465399558391.

[15] Flesch, M. 1986. Tax Avoidance: The Attitude Of The Courts And The Legislature. Current Legal Problems, 21, 215-38.

[16] Fofana , I., Corong, E. L., Chatti, R., Bibi, S. \& Bouazouni, O. 2012. Taxation Policy And Gender Employment In The Middle East And North Africa Region: A Comparative Analysis Of Algeria, Egypt, Morocco, And Tunisia. Ifpri Discussion Paper No. 01227, Http://Ssrn.Com/Abstract $=2185020$.

[17] Fortin, B., Lacroix, G. \& Villeval, M. C. 2007. Tax Evasion And Social Interactions. Ssrn Electronic Journal. http://dx.doi.org/10.1016/j.jpubeco.2007.03.005.

[18] Garbarino, C. 2011. Aggressive Ta X Strategies And Corporate Ta X Governance: An Institutional Approach. European Company \& Financial Law Review, 8, 277-304. http://dx.doi.org/10.1515/ecfr.2011.277.

[19] Gronbacher, G. M. A. 1998. Taxation: Catholic Social Thought And Classical Liberalism. Journal Of Accounting, Ethics \& Public Policy, 1, 158-167.

[20] Hanlon, M. \& Slemrod, J. 2009. What Does Tax Aggressiveness Signal? Evidence From Stock Price Reactions To News About Tax Shelter Involvement. Journal Of Public Economics, 93, 126-141. http://dx.doi.org/10.1016/j.jpubeco.2008.09.004.

[21] Hessing, D. J., Kinsey, K. A., Elffers, H. \& Weigel, R. H. 1998. Tax Evasion Research: Measurement Strategies And Theoretical Models

[22] Kluwer. In W. Van Raaij, G. Van Veldhoven,. \& K. Wärneryd (Eds.), Handbook Of Economic Psychology, 515-537.

[23] Lefebvre, M., Pestieau, P., Riedl, A. \& Villeval, M. C. 2011. Tax Evasion, Welfare Fraud, And The Broken Windows Effect: An Experiment In Belgium, France And The Netherlands. . Iza Discussion Paper No. 5609.

[24] Levin, J. \& Widell, L. M. 2014. Tax Evasion In Kenya And Tanzania: Evidence From Missing Imports. Economic Modelling, 39 http://dx.doi.org/10.1016/j.econmod.2014.02.021.

[25] Lim, Y. 2011. Tax Avoidance, Cost Of Debt And Shareholder Activism: Evidence From Korea. Journal Of Banking \& Finance 35, 456-470. http://dx.doi.org/10.1016/j.jbankfin.2010.08.021.

[26] Lipatov, V. 2012. Corporate Tax Evasion: The Case For Specialists. Journal Of Economics Behavior And Organization, 81, 185-206. http://dx.doi.org/10.1016/j.jebo.2011.09.015.

[27] Mcgee, R. 1998a. Christian Views On The Ethics Of Tax Evasion. Journal Of Accounting, Ethics \& Public Policy 1, 210-225.

[28] Mcgee, R. 1998b. The Ethics Of Tax Evasion. Dumont, Nj: The Dumont Institute For Public Policy Research.

[29] Mcgee, R. 1999a. Is It Unethical To Evade Taxes In An Evil Or Corrupt State? A Look At Jewish, Christian, Muslim, Mormon And Baha'i Perspectives. Journal Of Accounting, Ethics \& Public Policy, 2, 149-181.

[30] Mcgee, R. 1999b. Why People Evade Taxes In Armenia: A Look At An Ethical Issue Based On A Summary Of Interviews. Journal Of Accounting, Ethics \& Public Policy, 2, 408-416.

[31] Mcgee, R. \& Maranjyan, T. 2006. Tax Evasion In Armenia: Causes, Cure And Policy Implications. Ssrn Electronic Journal http://dx.doi.org/10.2139/ssrn.878396.

[32] Mcgee, R. \& Yoon, Y. 2014. Chapter 15 - Attitudes Toward Tax Evasion In Korea: A Study In Public Finance. Handbook Of Asian Finance: Financial Markets And Sovereign Wealth Funds. Financial Markets And Sovereign Wealth Funds.

[33] Mcgee, W. 2005. The Ethics Of Tax Evasion: A Survey Of International Business Academics. 60th International Atlantic Economic Conference, New York, October 6-9, 2005. Also Available At Www.Ssrn.Com.

[34] Mcgee, W., Nickerson, I. \& Fees, W. 2005. When Is Tax Evasion Ethically Justifiable? A Survey Of German Opinion. . Proceedings Of The Academy Of Legal, Ethical And Regulatory Issues, Vol. 9, No. 2, Pp. 35-38, Las Vegas, October 12-15.

[35] Mughal, M. M. \& Akram, M. 2012. Reasons Of Tax Avoidance And Tax Evasion: Reflections From Pakistan. Journal Of Economics And Behavioral Studies, 4, 217-222.

[36] Otusanya, J.-O. 2011. The Role Of Multinational Companies In Tax Evasion And Tax Avoidance: The Case Of Nigeria. Critical 
Perspectives On Accounting 22, 316-332. http://dx.doi.org/10.1016/j.cpa.2010.10.005.

[37] Pommerehne, W., Hart, A. \& Frey, B. 1994. Tax Morale, Tax Evasion And The Choice Of Policy Instruments In Different Political Systems. Public Finance, 49, 52-69.

[38] Smith, S. R. \& K., K. C. 1998. Tax Evasion And Ethics: A Perspective From Members Of The Church Of Jesus Christ Of Latter-Day Saints. Journal Of Accounting, Ethics \& Public Policy, 1.

[39] Torgler, B. 2002. Speaking To Theorists And Searching For Facts: Tax Morale And Tax Compliance In Experiments. Journal Of Economic Surveys, 16, 657-683. http://dx.doi.org/10.1111/1467$\underline{6419.00185 .}$

[40] Uadiale, O. M., Fagbemi, T. O. \& Ogunleye, J. O. 2010. An Empirical Study of The Relationship Between Culture And Personal Income Tax Evasion In Nigeria. European Journal Of Economics, Finance And Administrative Sciences, 20, 116-126.

[41] Wilson, R. 2009. An Examination Of Corporate Tax Shelter Participants. The Accounting Review, 84, 969-999. http://dx.doi.org/10.2308/accr.2009.84.3.969.

[42] Yitzhaki, S. 1974. A Note On Income Tax Evasion: A Theoretical Analysis. Journal of Public Economics, 3, $201-202$. http://dx.doi.org/10.1016/0047-2727(74)90037-1. 